\title{
The Impact of the Covid-19 Pandemic on the World of Education in Indonesia
}

\author{
Novianita Rulandari \\ The STIAMI Institute of Social Sciences and Management \\ novianitarulandari@gmail.com
}

Submitted : September 25, 2020 Revised : October 17,2020 Published : October 31, 2020

\begin{abstract}
Since the beginning of 2020 the world has been shocked by the Corona Virus Diseases (Covid19) pandemic which has spread rapidly throughout the world, infecting more than fourty millions of people, causing more than one million deaths by October 2020. This pandemic has impact on education world where all levels of education from kindergarten to postgraduate are required to carry out distance learning through online-based classes. Various problems then arise in distance learning because not all students have the facilities and infrastructure needed in its implementation, even causing casualties. This research examines and discusses the phenomenon of the Covid-19 pandemic and its impact on education world in Indonesia. The purpose of this research is to find out government policies in overcoming learning problems in a pandemic situation and finding the right policies so that learning can still be carried out effectively, how the supervision needs to be done by the government so that teaching and learning activities can run effectively and how the teaching communication strategies in using online media so that the delivery of material by lecturers can be easily understood by students. From the research results, several conclusions were obtained. The Minister's policy to carry out the online learning process still faces various challenges in its implementation; The learning process from home must always be monitored through good cooperation between students, parents and educators, especially for primary and secondary education; and by using some appropriate learning communication strategies, the online teaching and learning process can be carried out more effectively because it does not take up a lot of time and space.
\end{abstract}

Keywords: Covid-19, Pandemic Impact, Online Learning Strategy, Educational Communication

\section{INTRODUCTION}

Since the beginning of 2020, the world has been shocked by the Corona Virus Disease (Covid-19) pandemic which has spread so rapidly throughout the world. The first case of Covid19 in Indonesia was announced directly by President Joko Widodo on Monday, March 2, 2020, amid doubts from a number of countries and the World Health Organization (WHO) about the ability of the Indonesian government to handle the Covid-19 pandemic(Wajdi, Kuswandi, et al., 2020; Wajdi, Ubaidillah, et al., 2020). At that time, the President announced that two Indonesian citizens, a 64-year-old mother and 31-year-old daughter, a resident of Depok City, West Java, tested positive for Covid-19.

Until October 20, 2020, or seven months since the President's announcement, the number of positive sufferers of Covid-19 in Indonesia has reached 365,240 people with the number of deaths reaching 12,617. 222 of them are victims of health workers consisting of 130 doctors and 
92 nurses who are fighting on the front lines against the Covid-19 pandemic. Indonesia is the country with the highest mortality rate in Southeast Asia, which is around 3.5\%.

Efforts to minimize the spread of the Covid-19 pandemic namely are physical distancing, wearing masks, and washing hands using soap. Some local governments even carry out operations for those who do not wear masks in public places by imposing sanctions in the form of oral and written warnings, social work and even fines. However, this policy drew criticism because it was considered ineffective in preventing the spread of Covid-19. The Covid-19 pandemic also has a wide impact on the world of education, where the learning process can no longer be done face-to-face in classrooms, because there is a chance that the Covid-19 pandemic will spread. Therefore, the entire teaching and learning process is carried out through the Distance Learning system using online media.

In the last decade the development of online media is very rapid even it can be said that there has been an online media revolution. Nowadays, online media is more difficult to define because it is no longer limited to a communication instrument that can be used in two-way communication. Online media today is completely different from online media that first appeared at the beginning of the new millennium. Previously online media were limited to conversations in cyberspace, and could only be accessed through a large set of computers that have low-speed internet access. Currently, online media can be accessed via smartphones with high-speed internet connections, so besides being used for chatting, it can also be used for sending, photos, sounds, videos and large documents. (Edosomwan et.al., 2011)

These days, online media are not only tools to connect with others, but more than that it is a tool for the dissemination of video news, promotional tools, tutorials, support, even political campaigns. This is because online media provides a variety of features that support the dissemination of information to unlimited number of audiences (Cohen, 2009).

This is certainly an impact on the relationship between users who are increasingly tenuous, even among online media users now rarely know each other in the real world. In the beginning, online media was a tool to connect users in one community online, for example the alumni community of certain universities, the doctor community, the automotive community, the animal lover community, and others. Of course the members of this community already know each other in the real world but want to build closer relationships through an online media. Online media now engages more audiences and users, so it is able to connect people from all over the world who have never known each other before. Online media users now don't have to use their real profile, so many online media users use fake identities and addresses. (Hartshorn, 2010).

Online media is a system or channel of communication that makes it difficult to get the right response or answer as expected. This happens because online media users don't know you. In contrast, online media are a medium for conducting two-way communication, where conversation becomes the core of communication with the people we have chosen before, so that online media can be used to develop more intense relationships. (Bedell, 2010).

In the world of education, the availability and access to information so quickly expected to stimulate the growth of fresh ideas in the form of innovation and creation early on. The creativity of the younger generation can be honed by utilizing online media while still promoting the spirit of local wisdom. In digital platforms like Youtube there are many teaching shows that can be used as learning tools to develop students' talents and abilities. At the tertiary level, digital start-up innovation can be optimized by elevating creativity that elevates the implementation of 
work according to the Tri Dharma of Higher Education. Higher educations must become a bridge of innovation and a forum for interaction and collaboration with communities in need.

In the book Disruption Era: Opportunities and Challenges of Indonesian Higher Education, Oey-Gardiner et al. (2017) mention the current era of disruption is feared, when students are free to choose and learn for themselves everything they want to know. The era of disruption is actually the results of research activities and technological innovation that can be a new starting point for Indonesian universities in developing various new methods in the field of education. Former Ministry of Education, Mohamad Nasir, in a seminar said that old literacy such as reading, writing, and counting as capital had been obtained, then must be supported by understanding new literacy, namely data literacy, technology literacy and human literacy.

The spread of the Covid-19 pandemic that is so deadly today is a crisis that is currently hitting humanity. We cannot avoid this crisis, but must be faced together by the whole society. A crisis is basically an event that does not go well and causes instability to an individual or a group of people. A crisis is a condition that will threaten the integrity or survival of an individual or group. Crises can occur because of information that is not in accordance with facts and can also occur because of communication that is not going well.

To deal with the current crisis, all stakeholders must work together in efforts to prevent and handle this Corona Virus. Currently, all parties, starting from the local government, universities, communities, the media must be ready to work together to provide actual and clear information, so there is no confusion of information. Various efforts to minimize risks must be made so that they can suppress and reduce the spread of Covid-19.

The world of national education has responded to the Covid-19 pandemic by eliminating face-to-face teaching and learning activities and replacing them with online teaching and learning activities for all levels. This effort was made to avoid the spread of the Covid-19 pandemic in educational institutions, although the effectiveness of this policy still needs to be studied considering that not all students and students comply with the advice to learn from home, but take advantage of this moment for a vacation.

Until now, all levels of education are required to carry out Distance Learning through online-based classes or also called online learning to differentiate it from offline learning. Distance Learning requires time and careful preparation, fortunately for educational units that already have distance education facilities and infrastructure so that it only remains to use and develop them. This pandemic provides a challenge for all education units to continue to provide optimal service to their students. Some education units are not able to face this challenge, and the impact on the teaching and learning process is not carried out properly and is threatened with closure.

Most of the education units in big cities have succeeded in developing online learning in a short time and they still carry out the teaching and learning process online using various media. Some educational units already have their own applications, but most use popular video conferencing applications such as Zoom and Google Meetings. Apart from these two applications, the teaching and learning process can also use Skype, WhatsApp Group application, Google Classroom, Cisco Webex, Apple Facetime, and ConnectWise Control.

To prevent the spread of this pandemic, the Ministry of Education and Culture of the Republic of Indonesia (Kemendikbud RI) has issued several policies so that education units can still carry out the teaching and learning process online. The problems in this study are: 
The Impact of the Covid-19 Pandemic on the World of Education in Indonesia Rulandari

1. What is the government policy to address learning problems in a pandemic situation like this? What is the right policy so that learning can still be carried out effectively?

2. What supervision needs to be carried out by Kemendikbud so that the effectiveness of Distance Learning runs well?

3. What are good communication techniques when using conference media so that the delivery of material by lecturers can be easily accepted and absorbed by students?

\section{METHODS}

This research uses descriptive qualitative method. The data collection techniques used were observation and online interviews. The informants in this study were educators, policy makers and policy implementers in the education sector. The research analysis conducted was a three-step analysis, namely data reduction, data presentation and conclusion drawing.

\section{RESULTS AND DISCUSSION}

\section{Government Policies in the Education Sector in the Covid-19 Pandemic Situation}

The spread of the Covid-19 pandemic globally poses major challenges for all countries in the world in various sectors of life, including the education sector. The government, through the Ministry of Education and Culture, has issued various policies to prevent the spread of the pandemic, including online teaching policies and removing national final exams. Through Circular Number 3 of 2020, concerning the Prevention of Covid-19 in the Education Unit, the Minister of Education and Culture, Nadiem Makarim instructed all Education Units at all levels regarding technical instructions for preventing the spread of Covid-19 in Indonesia. There are three technical guidelines arranged according to risk categories, namely low, medium and high. This Circular Letter takes effect one week from the announcement of the first positive case of Covid-19 in Indonesia, namely since March 9, 2020. At that time, all education units from kindergarten to tertiary institutions immediately moved the face-to-face learning process to online teaching.

At the beginning of the implementation of this policy, many kinds of technical problems were found in the field, because not all students had adequate facilities to take part in online learning activities. To take part in online learning activities, a student must have at least an adequate device in the form of a smartphone (smartphone) based on Android or iOS that has installed a video conference application such as Zoom or Skype. After the device is available, students also need a stable internet connection (4G / LTE) and of course an adequate internet quota.

The video conferencing application is an application that requires a large quota and a stable signal, so that if these two things are not met, the teaching and learning process will face obstacles. From the results of a survey conducted by the Ministry of Education and Culture, the biggest obstacle faced by students is the availability of adequate devices to install the application. For some students who are economically able, this is not an obstacle. However, for some other students, smartphone devices and internet connections are still luxury items, and the learning process online is not possible for them.

Some universities overcome this by limiting the learning time from 2-3 hours of face-toface lectures to a maximum of 30 minutes. This is done to ease the burden on students who have limited internet access. Another way is to take advantage of messaging and social media applications such as LINE, Telegram, Instagram and Facebook, which do not require too much 
internet quota, although it eliminates the interactive aspect, because it is text and photo based, not video based. However, they argued that the most important thing was that the lecture material was conveyed well.

After at the beginning of the implementation of the online teaching and learning process experiencing many obstacles, now students and teachers are starting to be able to carry out these activities properly. Some cellular operators even provide special low-cost quota for accessing video conferencing applications. Even the Ministry of Education and Culture provides assistance in purchasing quotas for all levels of education units. This is of course very helpful for students who have limited internet quota. On the institutional side, several universities provide subsidized internet access for underprivileged students. Students only need to register their name, to get a limited quota that can only be use to access video conference application.

If in several big cities the online learning process can be carried out properly because it is supported by an adequate 4G / LTE internet connection, the students in various remote areas that have not 4G / LTE connectivity, rely on 3G/HSDPA connectivity, there are those who still use 2G / GPRS connectivity, even then the signal strength is still less stable. With these conditions, the implementation of Distance Learning is very difficult and even impossible to do. The suicide case of a high school student in Gowa, South Sulawesi who get depressed because of piling up school work due to not having internet access can certainly be an evaluation in implementing Distance Learning.

The next challenge is the competence of teaching staff, both teachers and lecturers, in using online-based applications. As is known today there are still many senior teaching staff over 60 years of age who are still supporting certain courses due to the limited number of professors in the field of science. These senior teachers usually do not understand how the latest communication technology devices work, even just send text messages (SMS) they still have difficulty. With this condition, the lecture needs the help of an assistant to operate the information technology device used. However, from the results of the evaluation carried out, some senior lecturers prefer a practical way by giving assignments that must be submitted in hard copy. This method certainly invites risks because students have to leave the house and are vulnerable to being exposed to Covid-19 while outside the home.

The last challenge that was found in the online teaching and learning process due to the Covid-19 pandemic was the constraints of the relationship between parents, students and teachers, especially at the pre-school to high school education levels. Some parents of students still do not understand the meaning of learning from home so they think that students have been closed due to the Corona pandemic. Attitudes like this make them pay less attention to the learning process at home which they should supervise and assist. In fact, because he felt that his child had been closed off, the opportunity was used to return to his hometown or vacation to tourist attractions which of course contradicted the purpose of issuing a learning from home policy. Parents of students should play a more active role in replacing the role of teachers in school as long as their children undergo the learning process from home. To overcome this, the education unit is required to continuously provide guidance and direction to parents of students regarding the objectives of implementing the learning policy from home.

Behind the various challenges that have occurred in implementing learning from home as a result of the Covid-19 pandemic, several opportunities have emerged for changes in habits and good behavior in today's education world. One of them is the opportunity to maximize the use of communication technology in education. Developed countries that have implemented the 
Industrial Revolution 4.0 have not experienced culture shock when they have to shift the face-toface learning process into online learning from home. This is because so far they have been accustomed to carrying out the learning process through the use of communication technology as it is today, for example when a lecturer is unable to attend to give lectures because he is abroad to attend a conference. Meanwhile in Indonesia, communication technology such as smartphones and 4G / LTE connectivity are still luxury items for most people.

The Minister of Education and Culture as a policy maker gives flexibility to each education unit to get around various obstacles and challenges to the online teaching and learning process, but still avoiding students leaving the house to prevent the spread of Covid-19. In terms of policy, Law no. 20 of 2003 concerning the National Education System has regulated the implementation of distance education using internet facilities in detail. One of them in Article 31 paragraph 2 states that the distance education system functions to provide educational services to students who for some reason cannot carry out face-to-face educational activities. Furthermore, in the same article, paragraph 3, it is further stated that distance education is implemented using various forms of methods and coverage with the support of learning facilities such as the internet. The internet is defined as a communication and information technology network that connects various parties in the distance education process or online teaching and learning process.

\section{Supervision of the Online Teaching and Learning Process}

The biggest challenge in distance learning is the difficulty of carrying out supervision in its implementation. This is especially for elementary to secondary education units. The students who are under the age of 7 to 16 years generally do not have the awareness to carry out independent learning without the supervision of educators. Even in students who have aged 17 years and over are still found this way.

In the online teaching and learning process, the role of parents is vital in supervising their children to comply with the policy. Primary and secondary school students use the internet more as an entertainment and play tool. During this time they were not directed to use smartphones and its applications as learning tools. Therefore, when they are then required to learn by using a smartphone as a tool, they use it to play games. This is compounded by the attitude of parents who do not care about the learning process of their children so far.

When suddenly the teacher gives the responsibility to parents to oversee the learning process of their children, what happens next is the attitude of rejection and indifference of the parents. Yet in Law Number 20 of 2003 concerning the National Education System, it is stated that parents have an important role to oversee the education process of their children. Teachers only act as supervisors while the students are in an educational facility environment, while parents become supervisors of their children at home. When the distance learning process is carried out online at home, then the task of supervision becomes the responsibility of each parents.

In the evaluation carried out by the ministry, several factors were found to cause supervision of the teaching and learning process online that could not run properly, particularly from the parents' side of the students. One of them is the attitude of parents who do not care about the learning process being carried out by their children. This indifference is caused by parents' limited understanding of using online learning applications and the inability of parents to guide their children in doing the tasks given by the school. Some parents of students stated that 
they did not understand or were not able to use online learning tools, so they could not carry out the teaching and learning process online properly.

The biggest obstacle in monitoring distance learning process is the parents' lack of understanding of the learning materials that their children receive. So when teachers give assignments online, parents have difficulty directing their children to complete these tasks. Based on reports from several education units, there is a wide gap in the results of online daily examinations between students who are supervised and mentored by their parents and students who are not. Some students get very high test scores, while others get fairly low test scores.

To overcome this problem, the education unit seeks to provide guidance to students' parents in providing supervision to their children. Although the results are not optimal, parents become more concerned about the learning process of their children. The results can be seen from the increase in scores achieved in the daily exam.

Monitoring the teaching and learning process online is the most difficult thing to do because it involves the active role of parents in supervising their children. Various obstacles are faced in its implementation, because not all parents have the same understanding, and have different educational backgrounds.

\section{Effective Communication Strategies in Teaching and Learning Online Process}

The process of teaching and learning online is not just moving face-to-face learning from classrooms to distance learning, but more than that, distance learning processes require all educational units at all levels to find effective online teaching communication strategies. The various obstacles and challenges of the distance learning process that have been discussed in this paper require the right solution so that educational goals are still met.

The main strategy is related to human resources or the competence of educators. At present in Indonesia there are 3 million educators with diverse competencies. Most Indonesian educators already have the ability to carry out online teaching and learning through video conferencing applications, because at least every educator has attended elementary or beginner distance education or training.

However, in distance learning process each educator is also required to have an advanced ability to make teaching materials online based on competencies created by UNESCO. According to UNESCO, every teaching staff must have the competence to prepare a learning system, syllabus, and learning methods according to the needs determined by the education unit.

The process of distance learning is certainly very different from face-to-face learning in the classroom. Educators are not enough to photograph teaching material in printed form and then sent to each student to be read and study. But every educator is required to be able to take advantage of online-based applications that are now widely available. The education unit can budget for the purchase of learning applications, comprehensive examinations and online-based education evaluations, so that it is completely paperless. The education unit can also facilitate the procurement of hardware such as laptops and cameras that support the smooth teaching and learning process online, including the provision of high-speed internet connections for all teaching staff in the education unit.

To improve the competence of teaching staff, of course, they must hold training which consists of several levels, starting from the basic level to the advanced level. All such training must be carried out online in the midst of the current Covid-19 pandemic, and must also be carried out briefly in a period of less than 7 days. To speed up this process, educators who are already competent can pass these skills on to other educators as a training for trainer. 
The next strategy is to limit online learning time to a maximum of 15-30 minutes for each learning session. In each session the educator only conveys the core of the subject matter in the form of points and provides a link for students to learn more material. Complete material for each learning session can be sent via email and cloud computing to be studied in depth by each student. The discussion and question and answer process can be carried out through a messaging or chat applications available on a variety of platforms.

The last important strategy, is when evaluating learning can use online exam applications such as CAT, CBT, FlyExam and others. By using the online exam application, the results can be seen as soon as the participant has finished the exam. Learners can also find out the Grade Point Average (GPA) faster than written tests in classrooms.

By using several learning communication strategies above, the online teaching and learning process can be implemented more effectively because it does not take up much time and place. Educators and students can carry out the learning process without leaving home which is certainly risky in the midst of the current Covid-19 pandemic.

Advances in communication technology currently open the opportunity for the implementation of the Industrial Revolution 4.0 in the education sector where face-to-face lectures are no longer the main media in the learning process, but rather prioritize the use of communication technology to the maximum as developed countries have applied it first in various sectors of life.

\section{CONCLUSION}

The Minister's policy to carry out the online learning process is still faced with various challenges in its implementations. The challenges include the limitations of communication technology resources, such as internet connectivity and adequate devices, inequality of communication technology in urban and remote areas, limited competence of teaching staff in using communication technology devices, and the relations of students, parents and instructors who have an different understanding in looking at the Covid-19 pandemic and the policy of learning from home.

The distance learning process from home must always be monitored through good collaboration between students, parents and educators, especially for primary and secondary education. Parents of students are required to be able to play roles as teachers at home for their children. Whereas at the college level the supervision of the learning process from home is more dependent on the awareness of the lecturers and their students in complying with the learning policy from home.

By using some appropriate learning communication strategies, the online teaching and learning process can be carried out more effectively because it does not take up much time and place. Educators and students can carry out the learning process without leaving home which is certainly risky in the midst of the current Covid-19 pandemic.

The advancement of communication technology that is currently open opportunities for the implementation of the Industrial Revolution 4.0 in the education sector where face-to-face lectures are no longer a major media in the learning process, but rather prioritize the use of communication technology to the fullest as developed countries have been first applying it in various sectors of life. 
The Impact of the Covid-19 Pandemic on the World of Education in Indonesia

Rulandari

\section{REFERENCES}

Bedell, J. (2010). What is the Difference Between Social Media and Social Networking? http://jasontbedell.com/what-is-the-difference-between-social-media-and-socialnetworking.

Cohen, L. S. (2009). Is There A Difference Between Social Media And Social Networking? http://lonscohen.com/blog/2009/04/difference-between-social-media-and-socialnetworking/

Edosomwan, S. (2011). The History of Social Media and its Impact on Business. The Journal of Applied Management and Entrepreneurship, 2011, Vol. 16, No.3.

Hartshorn, S. (2010). 5 Differences Between Social Media and Social Networking. http://www.socialmediatoday.com/SMC/194754

Pirillo, C. (2010). Social Media updates. http://chris.pirillo.com/what-is-ping-fm/

Surat Edaran Direktorat Jenderal Pendidikan Tinggi Kementerian Pendikan dan Kebudayaan Nomor 302 Tahun 2020 tentang Masa Belajar Penyelenggaraan Program Pendidikan.

Surat Edaran Menteri Pendidikan dan Kebudayaan Nomor 3 Tahun 2020 tentang Pencegahan Corona Virus Disease (Covid-19) Pada Satuan Pendidikan.

Undang-Undang Republik Indonesia No. 11 Tahun 2008 Tentang Informasi dan Transaksi Elektronik.

Waldman, S. (2011). The Information Needs of Communities. Washington DC: Federal Communications Commission.

Wajdi, M. B. N., Kuswandi, I., Al Faruq, U., Zulhijra, Z., Khairudin, K., \& Khoiriyah, K. (2020). Education Policy Overcome Coronavirus, A Study of Indonesians. EDUTEC: Journal of Education And Technology, 3(2), 96-106.

Wajdi, M. B. N., Ubaidillah, M. B., Mulyani, S., Anwar, K., Istiqomah, L., Rahmawati, F., Hikmawati, S. A., Ningsih, D. R., \& Rizal, H. S. (2020). Pendampingan Redesign Pembelajaran Masa Pandemi Covid-19 bagi Tenaga Pendidik di Lembaga Pendidikan berbasis Pesantren di Jawa Timur. Engagement: Jurnal Pengabdian Kepada Masyarakat, 4(1), 266-277.

Wright, Michelle F., (2016). Online Identity Construction. Journal of Computer-Mediated Communication volume 21/2016.

https://www.worldometers.info/coronavirus/

https://www.who.int/emergencies/diseases/novel-coronavirus-2019

https://www.cdc.gov/coronavirus/2019-ncov/index.html

https://covid19.go.id/

https://covid19.kemkes.go.id/category/situasi-infeksi-emerging/info-corona-virus/

https://kompas.com/ 